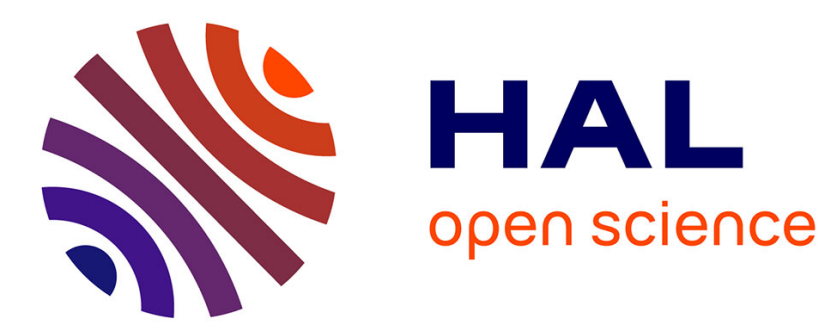

\title{
Enkū Beyond the Boom: Off or On the Tracks of Shugendō?
}

Robert Duquenne

\section{To cite this version:}

Robert Duquenne. Enkū Beyond the Boom: Off or On the Tracks of Shugendō?. Cahiers d'ExtrêmeAsie, 2009, p. 249-253. halshs-03134374

\section{HAL Id: halshs-03134374 \\ https://shs.hal.science/halshs-03134374}

Submitted on 8 Feb 2021

HAL is a multi-disciplinary open access archive for the deposit and dissemination of scientific research documents, whether they are published or not. The documents may come from teaching and research institutions in France or abroad, or from public or private research centers.
L'archive ouverte pluridisciplinaire HAL, est destinée au dépôt et à la diffusion de documents scientifiques de niveau recherche, publiés ou non, émanant des établissements d'enseignement et de recherche français ou étrangers, des laboratoires publics ou privés. 


\section{Enkū Beyond the Boom: Off or On the Tracks of Shugendō?}

\section{Robert Duquenne}

\section{Citer ce document / Cite this document :}

Duquenne Robert. Enkū Beyond the Boom: Off or On the Tracks of Shugendō?. In: Cahiers d'Extrême-Asie, vol. 18, 2009. Shugendō. The History and Culture of a Japanese Religion / L'histoire et la culture d'une religion japonaise pp. 249-253; doi : https://doi.org/10.3406/asie.2009.1340

https://www.persee.fr/doc/asie_0766-1177_2009_num_18_1_1340

Fichier pdf généré le 06/02/2019 


\title{
Rapports de recherche / Research Reports
}

\author{
ENKŪ BEyOND THE BOOM: \\ OfF OR ON THE Tracks OF SHUgendō?
}

\section{Robert DUQUENNE}

It is almost as a law in physics that the attention of the crowds centers on eccentrics and eccentricity, and that the boom thus initiated or ignited exerts a lasting saturation. Whatever the focus or victim of such a boom could have done or still endeavours to do only results in intensifying the effect of this law. (And some of the 'victims' are able enough to grow a philosophical sense about this effect and its practical potentialities). There is nothing to be done but to wait for the smoke to recede until a clearer view can be restored.

But there is no smoke without fire, and Enkū 傊空 is no stranger to the boom launched in the 1950's, with its first apex being an exhibition at the Kamakura National Museum of Modern Art in 1959: The venue itself illustrates the very character of this boom as a response of Japanese specialists in Western modern art to the outstanding originality of Enkü's sculptures (in those years, his few paintings were still unknown). And indeed, those sculptures are literally outstanding when compared to the atelier production of professional Buddhist sculptors of Enkü's time. Whatever the iconographical variety owed to the emergence of new cults, either from continental or autochthonous origins, sculpture after the $14^{\text {th }}$ century remains essentially religious and concentrates on reproduction or restoration of former models: it undergoes a constant decline, in striking contrast with the creativity of architecture, painting, calligraphy or ceramics.

"Literally outstanding" may sound a bit pompous but I beg it be understood within the limits of its literal meaning. The protohistory of Shugendo knows of Mangan Shōnin 満願 (or 萬卷) .上人 (720-818), the founder of three jingū $j i$ 神宮寺 in Kashima 鹿島 (749), Hakone 箱根 (759, where his sculpted portrait is enshrined), and Ise 伊勢 (763: Tado Jingūji 多度神宮寺) whose name refers to the vow he accomplished when he completed the recitation of ten thousand volumes (man-kan 萬苵): More precisely, ten thousand recitations of the Hökó-daishögon-gyo 方廣大莊榐經 in 12 volumes (T. 3, 187: Divākara's translation 680-688, of the Lalitavistara): to me it is still a mystery why he chose this text, a most extreme instance in the legendary developments of the life of the Buddha. But the only relevant point to stress here is that 12 times 10 thousand is 120 thousand, and in 1690, 28 years after his first dated sculptures, Enkū claims to have fulfilled his vow of producing 100 thousand 'bodies' (jümantai 十萬體), of which only 5,205 items of all sized have been authenticated by 2006 . The authentication of the remaining 4,795 items will be left to future generations. To be sure, all these 'bodies' are not as massive as his sculptures in Hokkaidō 北海道, Michinoku 陸奥 and Akita 秋田 (1666-1667: all together 72 items). Enkū's vow was made in the course of time as evidenced in an increasing 
number of smaller and swifter sculptures, culminating in two series of 'thousand bodies' at Ryūsenji 龍泉寺 and Arako Kannonji 荒子觀音寺 in Nagoya (1676) as well as the 'thousand Jizō' in the Jizōdō 地藏堂 of Tsushima 對馬.

The idea of such a vow may have occurred to him in 1674 while he was at Shima 志摩, Mie prefecture 三重縣, restoring two sets of the Daibannyakyo 大般若經 in 600 vols. At Sanzōji 三藏寺 in Katada village 片田村 and at the Yakushidō 藥師堂 in Agomachi 阿兒町, and supplying in each set the missing frontispieces mikaeshi 見返し with drawings of his own 54 and 62 respectively, based on the traditional image of Saakyamuni with his retinue of sixteen bodhisattvas, together with Xuanzang 玄牀, Jinsha taishō 深沙大將, and others (each drawing being in a more and more cursive style). Visibly, this "quantitative" concern in his sculptural works grows in the very spirit of a shakyo 寫經 practice, even if rather than copying scriptures he draws and carves images (his prolific poetry is alas also in the same spirit).

Whereas Mangan is but a prominent example among many other devotees in copying scriptures, Enkū in his own time had maybe only one emulator in Takuan 澤庆 (1573-1645), who devoted himself in drawing everyday an image of Fudō myōō 不動明王 and initiated thus a practice apparently specific to Rinzai 臨濟 monks, such as Hakuin 白隠 (1685-1768) and Sengai 仙崖 (1750-1837). Chronologically in-between comes Gyōdō Mokujiki 行道木喰 (1718-1810), who explicitly emulated Enkū in his sculptural work, however different his own inspiration.

As for Enkü's literally outstanding position in the history of Japanese sculpture, I would more specifically contrast his work with the so-called nata-bori 釷 彫 “hatchet carving" characteristic in the work of certain provincial ateliers in the $12^{\text {th }}-13^{\text {th }}$ centuries (mainly in Eastern Japan but also in Shiga 滋賀 and Hyōgo 兵 庫: possibly a Tendai tradition). The latter are works by professionally trained busshi 佛師, whose aesthetic intention it is to interrupt their work at the stage of rough carving (ara-bor $i$ 粗版) and refrain from further finition (ko-zukuri 小造り: polishing, lacquering and guilting). In a time when the Nara period intricate techniques of assembling (yosegi-zukuri 奇木造) were revived, the nata-bori carving marks a return to the ichiboku-zukuri - 木造 technique which prevailed in the $9^{\text {th }}-10^{\text {th }}$ centuries: this may be the only common aspect of atelier works in nata-bori carving and the sculptures by devoted but untrained artists such as Enkū and Mokujiki (who anyways both lacked the professional skill and possibly the patience to show proficiency in assembling techniques).

To have drawn the attention of academic specialists on these sculptures by religious practitioners (gyōja-kei cbōkoku 行者系彫刻) is one of the merits of Prof. Kuno Takeshi 久野健, but I hardly share his hopes of retracing antecedents to Enkü's work. Some traces of nata-bori do indeed survive in one only Jizō 地藏 statuette $(21 \mathrm{~cm}$.), signed in 1384 by a Mokujiki-gyōnin Ninkai 仁海, otherwise unknown, but too many "missing links" are required to extend a hypothetical filiation down to the Edo period. This filiation might eventually lead to Gyōdō Mokujiki, leaving Enkū aside: whatever Mokujiki's originality, a certain professional training is manifest through all his work, as well as the influence of late Ming imagery; and whatever his material or his subject, he hardly ventures beyond the formal frame of atelier conventions and the shaping of "ronde bosse." Quite not so in Enkü's 
case: he may have received some rudiments, hardly evidenced in his earliest dated statuettes of 1663-1664, but more so in his massive sculptures of the years 16661667 in Hokkaidō and northern Honshū, after a mysterious gap in 1665. Unlike Mokujiki, Enkū's technical progresses and his sense of proportions are constantly in the making: they visibly result from the experiments of an autodidact, whose inspiration widens with his keener attention to the planks and logs left at his disposal, their shapes and veinures, the teaching from the wood he is carving. In this we know him no master and, except the spiritual filiation claimed by Mokujiki, no disciples but too many plagiarists in the wave of the Enkū boom.

Nata-bori, the term itself, is a neologism created by art historians (possibly Kuno himself, for one), and the traditional and more accurate term for this type of sculpture is arabori 粗彫. To all sculptors it is evident that a nata 釷, a hatchet, is of little use even at this first stage of rough finition. Enkū's sculptures actually bear traces of various tools, and a whole set, traditionally given as his own, is piously preserved. Yet he is remembered as a miracle worker with a single hatchet as his only tool (nata ittcho 釷一挺): this at least is agreed upon by his two first biographers, both later by a century or even more and both interested in Enkü's "outstanding" position, however specific their own reasons for this interest:

Enkū's first biography, 95 years after his death, is included in the Kinsei-kijinden 近世畸人傳 “traditions about marginal men in recent generations," published in 1790 by Ban Kōkei 伴蓠蹊 (1733- 1806), a literate who hardly left his native Kyōto (where Enkū, to our knowledge has never been) and whose dilettantish interest is already inscribed in the title of his work: kijin "the people at the fringe of the field" are those who, in Zhuangzi's 莊子 words, are “marginals among the humans but equal to Heaven," who break off with everything in order to adhere only to Heaven, and the author's preface stresses that such people, the more obscure ones being the more virtuous, still existed in recent times. Enkü's second biographer, in 1844, is Zen'ei 全栄, by then the abbot of Jōkaisan Kannonji 淨海山觀音寺 in Arako 荒子 (Nagoya) and the author of the Jōkai-zakki 淨海雜記, “various records" about this monastery, where Enku received his instruction and first ordination as a master in Tendai precepts.

Of no consequence is their disagreement concerning Enkū's birthplace: Take-ga-hana 竹ヶ or Naka-no-mura 中村, both near nowadays Gifu-Hashima 岐 皁羽島, are barely distant by a $20 \mathrm{~km}$., but Naka-no-mura seems more likely, as it is there that Enku founded in 1670 a Kannon chapel to commemorate his mother (Uhōji 卯宝寺 in Zen'ei's text). This also favours Zen'ei's tradition about Enkū's origins: a Katō family 加藤氏 related to the Fujiwara clan 藤原氏 (possibly local landlords loosely related to this illustrious clan).

Illustrative of the respective concerns of both biographers is that Ban Kōkei extols Enkū's oracular gifts (however contradicted in later history), whereas Zen'ei dwells on imperial honours bestowed upon Enkū (very unlikely, but they are meant to enhance the position of his almost ruined monastery). More relevant is that both mention two sets of colossal temple guardians which are both extant: according to Ban Kōkei, the ones at Senkoji Senkōji 千光寺 in Takayama 高山 were carved directly in two standing trees (tachiki 立木), and the leftover chips were carved into 
a thousand figurines, which Enkū threw in an nearby pond to placate the evil spirit dwelling there; Zen'ei, no doubt, stays closer to reality when he records that the two guardians at Kannonji were erected at the gate after having been carved (in horizontal position, as normally done). The chips carved into a "thousand" figurines account for the great number of sculptures extant in Zen'ei's time and in ours: they have been retrieved in 1972, from a box hidden in the superstructures of the gate, and autograph inscriptions by Enkū identify them as Engaku 縁鲵, Shōmon 聲聞, Daijizaiten 大自在天, Bonten 焚天 and other avatars of Kannon according to the Fumonbon-chapter 曾門品 of the Lotus sütra.

Both authors agree about Enkū's last retreat at Mirokuji 彌勒寺 in Ikejiri 池尻 (near nowadays Seki 關市), where Enkū “took his end" (owari o toreri 終を取れり, in Ban Kōkei's cryptic euphemism) or, in Zen'ei's terms: "prepared for the pure act of rebirth yonder" (ojō no joggo 往生の浮業), which he accomplished in Genroku 元禄 8.7.15 (1695: the date on his gravestone at Mirokuji): this could refer to "entering

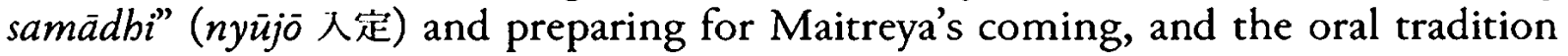
at Mirokuji would have been confirmed if all archives and other evidence had not been, together with Mirokuji itself, reduced to ashes in 1922 .

Both biographies are again following parallel and independent tracks concerning two major but successive episodes in Enkü's life. Ban Kōkei has no word about Enkü's training in the Tendai tradition and mentions, in the latter part of his biography, Enkū's early peregrinations in Ezo 蝦夷 territories (Hokkaidō), where he converted people and is remembered as Ima-shaka 今釋迦: Sākyamuni in this present time. Zen' ei, on the other hand is totally silent about this proselytizing activity in Ezo and puts forwards Enkū's more "orthodox" affiliation to the Tendai school.

Far from dramatically "running away from a certain monastery at the age of 23," as Ban Kōkei has it, Enkū went patiently through the initiation to both mandalas. Gyōki 行基 was his ideal model (Gyōki also inspired Saichō’s 最溌 bodhisattva ideal, and he is traditionally considered as the founder of several monasteries in Mino province 美濃琙, beginning with Kōdenji 高壮寺 in Kasugai 春日井, where Enkū underwent his first initiation, Arako Kannonji, and Mirokuji which he restored and adopted as his last retreat). Apparently but not explicitly in Zen'ei's words, Enkü's vow to carve 120.000 buddha "bodies" (bukku 佛挋) was inspired by this ideal, but one would also think of Mangan's 10.000 copies or 120.000 volumes and the copies of the Lotus sūtra which Saichō vowed to have enshrined in six stüpas throughout the country. In response to this vow, the deity on Mount Fuji is said to have given him the famous nata 釷 hatchet, but rather than Mount Fuji where Enkū left no trace to our knowledge, Hakusan n山 where Ban Kōkei locates a similar apparition has a far greater presence in Enkü's life and links him to yet another ideal model of the early $8^{\text {th }}$. century: Taichō 泰澄, who "opened the mountain" about the same time that En no gyoja 役行者 “opened” Kimpusen 金峯山, and whose descendants of the Nishigotō 西神预 priestly family were Enkū's first known patrons in 1663-1664.

Even if Enku ran from his monastery when young, there is no doubt that he resumed a more "orthodox" path in his maturity, but only then, and that he felt in need of recognition: in his own writings, he refers to a stay at Hōryūji 法隆寺 in 1671, and his admission into the Hossō 法相 lineage; dated sculptures attest a 
pilgrimage on Mount Ōmine 大峰山 in 1675 and maybe also two years before (in 1673 at Tenkawa 天川); all his training in the Tendai tradition follows later, at Onjoji 園城寺 (Miidera 井寺) in 1679 and 1689, before and after an initiation in rituals at Nikkō 日光 in 1682 and, in 1684 at Arako Kannonji, a formal recognition among the masters entitled to confer the bodhisattva precepts.

Born in 1632 (according to an autograph discovered only in 1976), he was already 32 at the time of his first dated sculptures (1663-1664) and there is hardly any clue to his activities during the previous years. Both rather close to Enkū's native province, Mount Ibuki 伊吹山 and Hakusan rather than Ōmine or Nikkō were his first retreats and always remained his references, however secondary by his time after a long history: earlier and more widely than Mount Hiei 比微山, they stood barring the evil influences threatening from the north-east the imperial palace (successively located in Yamato 大和, Ōtsu 大津 and Kyōto). Their geographic isolation favoured both their autonomy towards the capital and their openness towards the immigrants established in Ōmi 近江 and Echizen 越前 (respectively Saichō's and Taichō's native provinces). Hakusan alias Shirayama would owe its name either to the Silla 新羅 kingdom or to Paekdosan 白頭山 at the present border between Korea and Mandchuria, formerly at the centre of Bohai 渤海 kingdom. Echizen was also the maritime way to Northern Japan (safer and more frequented than the Pacific coast). In Enkū's time, both Echizen and Oshima peninsula 渡島半島 in southernmost Ezo were ruled by related branches of the Takeda clan 武田氏 and, without the Takedas' devoted patronage to Hakusan, one may wonder if Enkū ever would have embarked to Ezo.

As Ban Kōkei and against chronological evidence, I come at last to Enkū's early peregrinations in the Far North, which encompass the years 1666-1668, from his $35^{\text {th }}$ to his $37^{\text {th }}$ year of age. The repetitive character of his sculptures in this period made them less attractive to the esthetes surfing on the waves of the boom, their sacredness as "shintai" 神體 in local sanctuaries and more merely their weight are fairly reasonable grounds for their too rare display. Yet they are the only works to have been noticed already in the $18^{\text {th }}$ century and studied by local historians in prewar and pre-boom years. Some are, as nowhere else, garbed with legends and bearing in specific facial mutilations the traces of their later destiny. 